\title{
Feed restriction in growing rabbits: performance and digestibility
}

\author{
Restrição alimentar em coelhos em crescimento: desempenho e \\ digestibilidade
}

\author{
Restricción alimentaria en conejos de cebo: performance y \\ digestibilidad \\ ${ }^{1}$ Luiz Carlos Machado, ${ }^{2}$ Rosiane Souza Camargos, ${ }^{3}$ Eugênio Martinez-Peredez, \\ ${ }^{4}$ Caroline Gonçalves Silva de Faria, ${ }^{5}$ Jássia Melissa Morais Silveira, ${ }^{4}$ Victor Gabriel \\ Pereira da Silva, ${ }^{4}$ Dienas Luisa Pereira \\ ${ }^{1}$ IFMG Bambuí Campus, Brazil - luiz.machado@ifmg.edu.br \\ ${ }^{2}$ Animal science master's degree student - UNESP Jaboticabal - Brazil \\ ${ }^{3} \mathrm{UPV}$, Valencia - Spain \\ ${ }^{4}$ Animal Science students - IFMG Bambuí \\ ${ }^{5}$ Veterinary student - IFMG Bambui
}

\begin{abstract}
Strategies that reduce feeding costs became extremely important in the pandemic period, which provided a great increasing in the rabbit feeding costs. Feed restriction can improve intestinal health as well as to economize feed in the farm. This work aimed to evaluate the productive performance and digestibility in growing rabbits submitted to feed restriction. Therefore, 160 rabbits weaned at 32 days of age were distributed into two groups, which consisted of ad libitum and feed restriction. Rabbits with feed restriction received $50 \mathrm{~g}$ per day in the week after weaning, $100 \mathrm{~g}$ daily from 53 to 60 days of age and ad libitum from 39 to 53 and 61 to 74 days of age. Rabbits of the ad libitum group has free access to feed throughout all experimental period (32 to 74 days of age). For the digestibility assay, total faeces collection was performed using 10 animals from each treatment of the growing experiment. Rabbits with feed restriction were lighter at 39, 53 and 60 days, but reached 74 days with similar slaughter weight, showing compensatory growth. The productive performance of rabbits with feed restriction was impaired within the two restriction periods, with subsequent recovery. The treatments alternated superiority for daily weight gain in the different evaluated periods, although considering the entire period, there was similarity. Outside the restriction periods and considering the entire experimental period, daily feed consumption was similar, suggesting that there were no significant feed savings. Feed conversion was similar when consider all period. There were no significant effects on the digestibility coefficients of dry matter, organic matter and mineral matter. Feed restriction at the proposed levels can be used without impairing the performance of rabbits.
\end{abstract}

Key words: cuniculture, rabbit farm, feeding strategies.

\section{RESUMO}

Estratégias que reduzam os custos com alimentação tornaram-se extremamente importantes no período pandêmico, pois neste houve um grande aumento nos custos com alimentação dos coelhos. A restrição alimentar pode melhorar a saúde intestinal bem 
como economizar ração na granja. Este trabalho teve como objetivo avaliar o desempenho produtivo e a digestibilidade em coelhos em crescimento submetidos à restrição alimentar. Assim, 160 coelhos desmamados aos 32 dias de idade foram distribuídos em dois grupos, que consistiam em ração ad libitum e restrição alimentar. Os coelhos com restrição alimentar receberam $50 \mathrm{~g}$ diários na semana após o desmame, $100 \mathrm{~g}$ diários de 53 a 60 dias de idade e ad libitum de 39 a 53 e 61 a 74 dias de idade. Os coelhos do grupo ad libitum tiveram livre acesso à ração durante todo o período experimental (32 a 74 dias de idade). Para o ensaio de digestibilidade, a coleta total de fezes foi realizada com 10 animais de cada tratamento do experimento de crescimento. Coelhos com restrição alimentar foram mais leves aos 39, 53 e 60 dias, mas atingiram 74 dias com peso de abate semelhante, apresentando crescimento compensatório. O desempenho produtivo destes animais foi prejudicado nos dois períodos de restrição, com posterior recuperação. Os tratamentos alternaram superioridade para ganho de peso diário nos diferentes períodos avaliados, embora considerando todo o período, houve similaridade. Fora dos períodos de restrição e considerando todo o período experimental, o consumo diário de ração foi semelhante, sugerindo que não houve economia significativa de ração. A conversão alimentar foi semelhante ao considerar todo o período. Não houve efeitos significativos sobre os coeficientes de digestibilidade da matéria seca, matéria orgânica e matéria mineral. A restrição alimentar nos níveis propostos pode ser utilizada sem prejudicar o desempenho dos coelhos.

Palavras chave: cunicultura, granja cunícula, estratégias alimentares

\section{RESUMEN}

Las estrategias que reducen los costos de alimentación se volvieron extremadamente importantes en el período pandémico, pues en este hubo gran aumento en los costos de alimentación de los conejos. La restricción alimentaria puede mejorar la salud intestinal y ahorrar alimento en la granja. Este trabajo tuvo como objetivo evaluar la performance productiva y la digestibilidad en conejos en crecimiento sometidos a restricción alimentaria. Para ello 160 conejos destetados a los 32 días de edad fueron distribuidos en dos grupos, que consistieron en ad libitum y restricción alimentaria. Los conejos con restricción alimentaria recibieron $50 \mathrm{~g}$ diarios en la semana posterior al destete, $100 \mathrm{~g}$ diarios de 53 a 60 días de edad y ad libitum de 39 a 53 y de los 61 a 74 días de edad. Los conejos del grupo ad libitum tuvieron libre acceso al pienso durante todo el período experimental (32 a 74 días de edad). Para el ensayo de digestibilidad, se realizó la recolección total de heces utilizando 10 animales de cada tratamiento del experimento de cebo. Los conejos con restricción alimentaria fueron más ligeros a los 39, 53 y 60 días, pero alcanzaron los 74 días con un peso de faena similar, mostrando un crecimiento compensatorio. La performance productiva de los conejos con restricción alimentaria se vio afectada dentro de los dos períodos de restricción, con posterior recuperación. Los tratamientos alternaron la superioridad para la ganancia diaria de peso en los diferentes períodos evaluados, aunque considerando el período completo, hubo similitud. Fuera de los períodos de restricción y considerando todo el período experimental, el consumo diario de pienso fue similar, lo que sugiere que no hubo ahorros significativos de pienso. La conversión alimentaria fue similar al considerar todo el período experimental. No hubo efectos significativos sobre los coeficientes de digestibilidad de materia seca, materia orgánica y materia mineral. La restricción alimentaria a los niveles propuestos puede ser utilizada sin perjudicar la performance productiva de los conejos.

Palabras clave: cunicultura, granja de conejos, estrategias alimenticias. 


\section{Introduction}

Rabbit breeding is a strategic activity from a sustainable point of view, considering its economic, social and environmental spheres. In the pandemic period, the demand for pet rabbits as well as rabbit meat intensified. However, the high prices of commercial feed observed during this period in Brazil, contributed significantly to the reduction of the economic gains of the breeders for rabbit meat, which already worked with small profit margins (RISI, 2021). In this sense, alternatives that reduce production costs need to be developed and evaluated, especially those that optimize animal feeding.

One strategy to reduce the effect of rabbit enteropathy in Europe is related to the use of feeding restriction in the fattening period. In addition, several feeding plans and different programs have being proposed and applied, combining different fractions of ad libitum feed intake, feeding times, different ages or even different nutritional densities (GIDENNE et al, 2008b; ROMERO et al., 2010; BIROLO et al., 2017; GIDENNE, 2021, REBOUS et al., 2021).

Rabbits with feed restriction receive less amount of feed in the same period, which might lead to savings (GIDENNE et al., 2008b; OLIVEIRA et al, 2012). In addition, animals would adapt physiologically due to a shortage of nutrients, increasing the particle retention time (GIDENNE et al., 2008a). In this sense, benefits are reported on feed conversion rate (GIDENNE et al, 2008b; BIROLO et al., 2017), intestinal health (GIDENNE et al., 2008b; ROMERO et al,, 2010; GIDENNE, 2021), morphological structure of the small intestine (OLIVEIRA et al., 2013), increasing at the concentration of AGVs in the cecum, digestibility of crude protein and nitrogen retention (GIDENNE et al., 2008a) and reduction of the drug costs (GIDENNE, 2021). However, benefits on the digestibility of other nutrients have never been found yet (GIDENNE et al. 2008a; BIROLO et al., 2017). Even going through a period of feed restriction, there will be compensatory growth (GIDENNE et al., 2008b; ROMERO et al., 2010; OLIVEIRA et al, 2012; BIROLO et al., 2017; CAMARGOS et al., 2020). About behavioral aspects, feed restriction raise the feeding speed right after feed distribution (REBOUS et al., 2021). In Brazil, studies and application of feed restriction in rabbit farms are still incipient, although already exists an initial theoretical basis for indicating new strategies under Brazilian conditions. This work aimed to evaluate 
the performance and digestibility in crossbred rabbits that suffered feed restriction in two periods during their fattening period.

\section{Material and methods}

This research was carried out in the rabbit breeding shed of the Federal Institute of Science and Technology IFMG, Bambuí campus, from September 2019 to February 2020. The approval of the animal ethics committee was registered under the number 03/2017 CEUA-IFMG. The internal shed temperatures were measured daily, with average values of 19.5 and $30.9{ }^{\circ} \mathrm{C}$ for minimum and maximum, respectively.

One hundred sixty crossbred rabbits ( $1 / 2$ New Zealand White X $1 / 2$ Botucatu) of 32 days old (weaning age), both sexes, obtained from rabbit does of first and second cycles (two blocks), were housed in galvanized wire cages, size $1.00 \times 0.70 \times 0.50 \mathrm{~m}$ (length, width and height, respectively) and enriched with aluminum can, PVC pipe and second level platform. The cages contained two semi-automatic feeders and a nipple drinker. The two treatments consisted of ad libitum and feed restriction. In the restricted treatment, adapted from Oliveira et al. (2012) and Camargos et al. (2020), the animals received 50g/animal.day during the period from 32 to 39 days and $100 \mathrm{~g}$ /animal.day during the period from 53 to 60 days of age and ad libitum in the other periods (39 to 53 days and 60 to 74 days). Each repetition consisted of a cage with eight fattening rabbits (experimental unit) with a total of 10 repetitions per treatment. The guarantee levels as well as the analyzed composition of the experimental feed are described in table 1 .

Table 1 - Guaranteed levels and analyzed composition of the feed provided ad libitum or restricted for fattening rabbits

\begin{tabular}{lcc}
\hline \multicolumn{3}{c}{ Guaranteed levels } \\
\hline Parameter & Restriction & value indicated by the factory \\
\hline Dry matter (\%) & Minimum & 88.0 \\
Humidity (\%) & Maximum & 12.0 \\
Crude protein $(\%)$ & Minimum & 17.0 \\
Mineral matter (\%) & Maximum & 10.0 \\
Cruder fibber (\%) & Maximum & 15.0 \\
ADF (\%) & Maximum & 18.0 \\
Lipids $(\%)$ & Minimum & 2.90 \\
Calcium $(\%)$ & Minimum & 0.90 \\
Calcium $(\%)$ & Maximum & 1.00 \\
Phosphorus $(\%)$ & Minimum & 0.50 \\
\end{tabular}




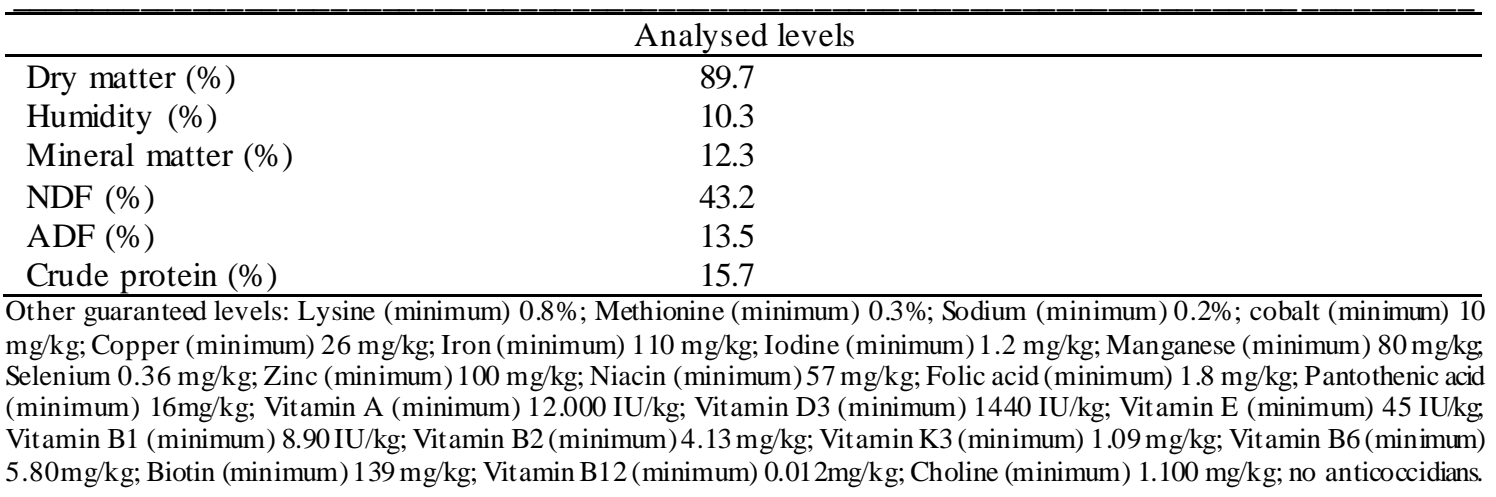

To measure the productive performance of fattening rabbits, live weight data were taken at 32 (W32), 39 (W39), 53 (W53), 60 (W60) and 74 (W74) days of age, daily weight gain in the periods from 32 to 39 (DWG32-39), 39 to 53 (DWG39-53), 53 to 60 (DWG53-60), 60 to 74 (DWG60-74) and 32 to 74 days of age (DWG32-74), daily feed intake in the periods from 32 to 39 (DFI32-39), 39 to 53 (DFI39-53), 53 to 60 (DFI53-60), 60 to 74 (DFI60-74) and 32 to 74 days of age (DFI32-74) and feed conversion between 32 to 39 (FC32-39), 39 to 53 (FC39-53), 53 to 60 (FC53-60), 60 to 74 (FC60-74) and 32 to 74 days of age (FC32-74).

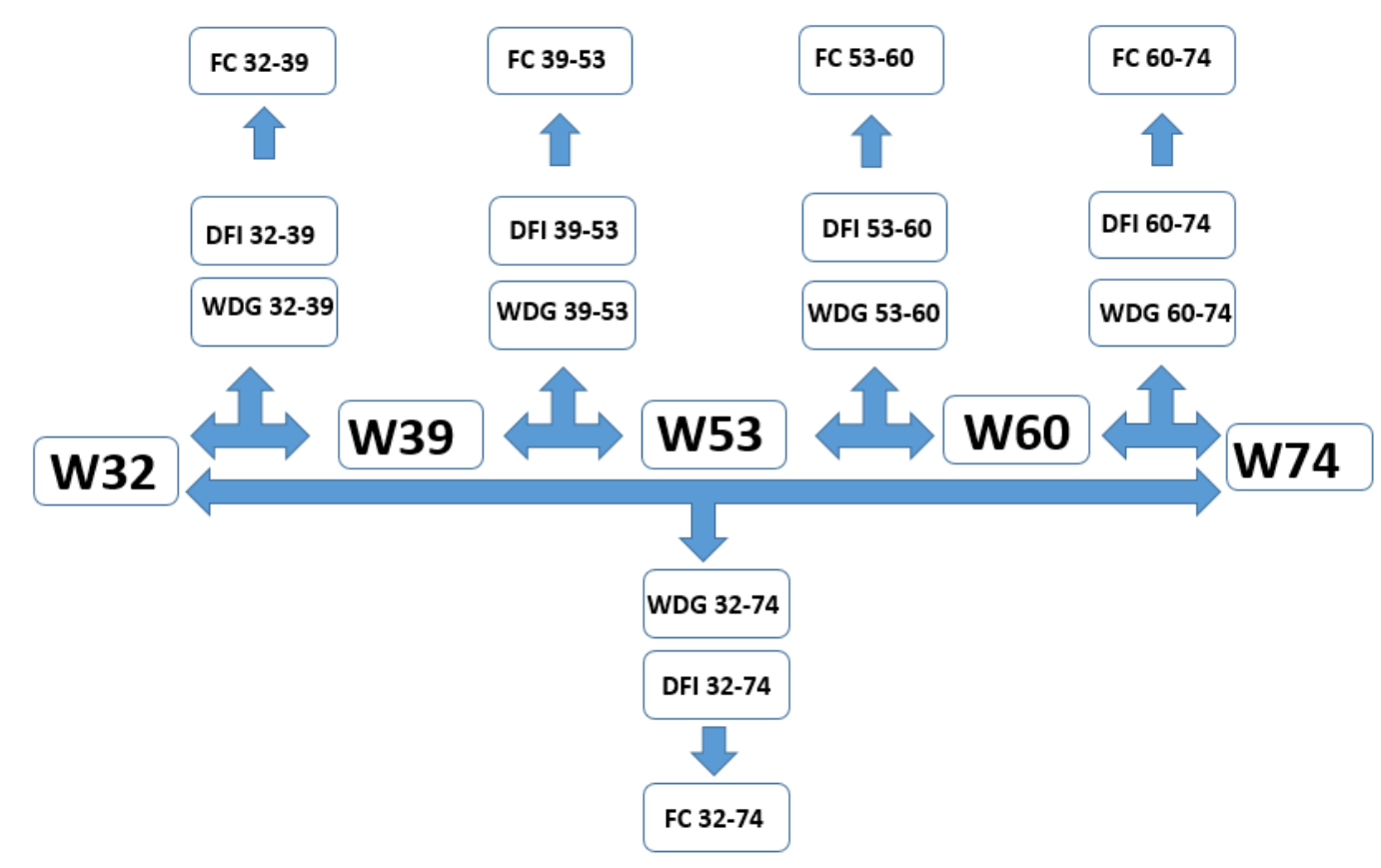

Figure 1 - Parameters taken for performance evaluation

For digestibility assay, 24 rabbits with 74 day of age were randomly selected and housed individually in cages equipped with fecal collection 
nets. Rabbits that wasted feed were excluded and thus 10 animals of each treatment continued until the end of the collection period. Then, a period of three days was used to adaptation to the new cage, plus four days for total collection of feces, which were stored in a freezer at $-18^{\circ} \mathrm{C}$. To evaluate these feces, predrying was carried out at $60^{\circ} \mathrm{C}$ for 72 hours, with the feces subsequently ground in an analytical mill as well as the experimental feed. After grinding, these materials were conditioned and left uncovered for a period of 24 hours for stabilization. The contents of dry matter $(\mathrm{DM})$, organic matter $(\mathrm{OM})$ and mineral matter (MM) were then determined. The dry matter content was determined using a methodology that uses oven equipment at $105^{\circ} \mathrm{C}$ during four hours and the mineral matter and organic matter contents were determined using a methodology that uses a muffle furnace at $600^{\circ} \mathrm{C}$ during four hours. The following equation was used to obtain the digestibility coefficients of DM, OM and MM:

$\mathrm{DC} i=((\mathrm{QN} i-\mathrm{QN} i \mathrm{E}) / \mathrm{QN} i) \times 100$

Where:

DCi: Digestibility coefficient of nutrient $i$

QNi: Quantity of intake nutrient $i$

QNiE: Quantity of nutrient $i$ excreted in the feces
For statistical analysis of

performance parameters, a randomized block design was used considering rabbits from the first and second cycles and ten repetitions per treatment. To analyze the digestibility coefficients, a completely randomized design with 10 replicates per treatment was considered. Analysis of variance was performed and the means were compared by the Tukey test at the level of 5\% probability, using the resources of the statistical programs SAS and SISVAR. For the parameters of live weight and daily weight gain, W32 was considered as a covariate.

\section{Results and discussion}

No rabbits died during the experimental period. It is noteworthy that rabbits in a fattening period in Brazil have a lower mortality rate when compared to Europeans (GIDENNE et al. 2008b, ROMERO et al., 2010).

Note that the rabbits with feed restriction were lighter at 39,53 and 60 days (table 2), but managed to reach 74 days with a similar weight to the animals that received ad libitum feed, thus demonstrating the occurrence of compensatory growth. Among the origin of the animals, those from the first birth were always heavier. There was probably a seasonal effect here, where the does weaned heavier kits in the 
spring period, when the temperature is

milder when compared to summer, and

this variation is related to a higher feed consumption by the rabbit does. The covariate W32 was significant for all weights evaluated.

Table 2 - Weights of rabbits that received ad libitum or restricted feeding, considering the period from 32 to 74 days of age

\begin{tabular}{lcccccc}
\hline Parameter & Restricted & Ad libitum & SE & Pgroup & Pbloc & Pbloc*group \\
\hline Live weight at 32 days (g) & 717.9 & 694.0 & 35.71 & 0.6419 & 0.0374 & 0.9252 \\
Live weight at 39 days (g) & 852.5 & 1006.6 & 12.61 & $<0.0001$ & 0.0598 & 0.9568 \\
Live weight at 53 days (g) & 1515.9 & 1572.6 & 13.76 & 0.0109 & 0.0026 & 0.8012 \\
Live weight at 60 days (g) & 1664.4 & 1822.8 & 16.12 & $<0.0001$ & 0.0078 & 0.2536 \\
Live weight at 74 days (g) & 2219.9 & 2259.1 & 21.78 & 0.2242 & 0.0040 & 0.4372 \\
\hline
\end{tabular}

SE: standard error

The blocs consider rabbits from the first and second cycles

Similarities in final weight between rabbits with and without feed restriction were also observed by Oliveira et al. (2012), Birolo et al. (2017), Camargos et al. (2020) and Rebous et al. (2021). The slaughter weight measured here would be insufficient to meet the Brazilian slaughterhouses, which suggest a slaughter weight minimum of $2.3 \mathrm{~kg}$ for rabbits, pointing the need to increase the fattening period if an intermediate quality commercial feed is used, as this one used in this work. It should be noted that the average weight at 74 days here is much lower than Birolo et al. (2017) and
Rebours et al. (2021) for rabbits at 70 and 68 days (2628.0 and 2826.3 respectively) suggesting that although there may be great differences in experimental conditions, there is still a long delay in Brazilian production conditions when compared to Europe.

Analyzing the DWG it is noted that the treatments alternated superiority in the experimental periods (table 3 and graphic 1). This trend was also observed by Gidenne et al. (2008b) and Camargos et al. (2020). Considering the entire experimental period, there is a similarity between the two different feeding strategies.

Table 03 - Daily weight gain in different periods of fattening of rabbits that received ad libitum or restricted feeding.

\begin{tabular}{ccccccc}
\hline Parameter & Restricted & Ad libitum & SE & Pgroup & Pbloc & Pbloc*group \\
\hline Daily weight gain 32-39 days (g) & 20.93 & 42.94 & 1.80 & $<0.0001$ & 0.0598 & 0.8136 \\
Daily weight gain 39-53 days (g) & 47.46 & 40.35 & 1.06 & 0.0002 & 0.0346 & 0.7812 \\
Daily weight gain 53-60 days (g) & 21.02 & 35.93 & 1.68 & $<0.0001$ & 0.4472 & 0.2045 \\
Daily weight gain 60-74 days (g) & 39.66 & 31.19 & 1.10 & $<0.0001$ & 0.1146 & 0.9111 \\
Daily weight gain 32-74 (g) & 36.04 & 36.98 & 0.52 & 0.2242 & 0.0040 & 0.4372 \\
\hline
\end{tabular}

Daily weight gain $32-74$ (g)

SE: standard error

The blocs consider rabbits from the first and second cycles 
Camargos et al. (2020) and Romero et al. (2010) obtained similar results and noticed a reduction in productive performance during the period of feed restriction. Note that the DWG obtained here is lower when compared to Gidenne et al. (2008b), Romero et al. (2010) and Birolo et al. (2017) (36.5 vs 41.0 vs 41.9 vs $46.7 \mathrm{~g}$ per day respectively), probably due to differences in the conditions of the genetics, ambience and feeding. However, even if adopted here intermediate quality feed, the values are higher than Oliveira et al. (2012).

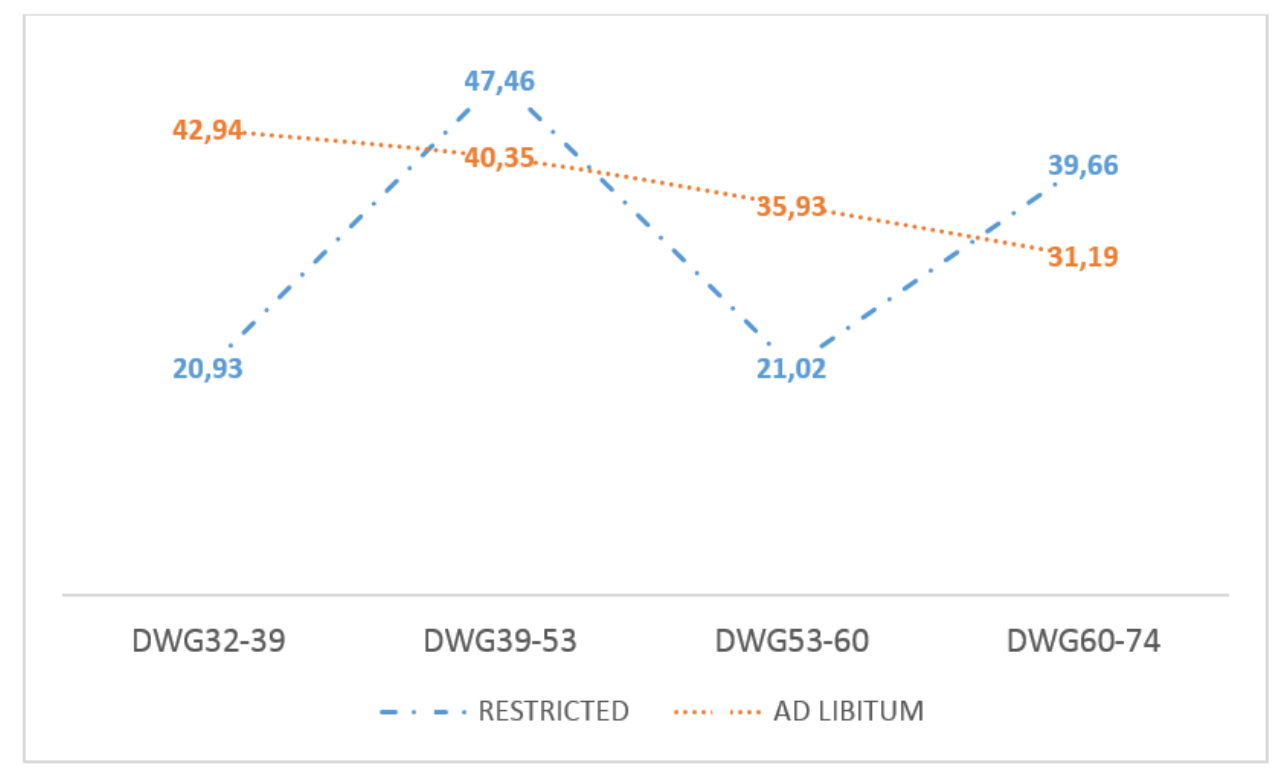

Graphic 1 - Daily weight gain of rabbits that received ad libitum or restricted feeding. DWG32-39: Daily weight gain from 32 to 39 days of age; DWG39-53: Daily weight gain from 39 to 53 days of age; DWG53-60: Daily weight gain from 53 to 60 days of age; DWG60-74: Daily weight gain from 60 to 74 days of age.

Obviously, the DFI in fattening rabbits that received ad libitum feeding was larger in the periods with feed restriction. It should be noted that even when eating a large amount of feed in the post-restriction period, there is a physiological limit. The similarity in the DFI32-74 does not corroborate with the idea of greater savings when adopting feed restrictions, although comparing only numerical values, restricted animals ingested $6.3 \%$ less feed.

Table 4 - Daily feed intake of rabbits that received ad libitum or restricted feeding at different periods during fattening period

\begin{tabular}{lcccccc}
\hline Parameter & Restricted & Ad libitum & SE & Pgroup & Pbloc & Pbloc*group \\
\hline Daily feed intake 32-39 days (g) & 50.0 & 90.4 & 3.07 & $<0.0001$ & 0.3465 & 0.3465 \\
Daily feed intake 39-53 days (g) & 120.5 & 115.6 & 4.37 & 0.4373 & 0.8834 & 0.3169 \\
Daily feed intake 53-60 days (g) & 100.0 & 145.0 & 3.16 & $<0.0001$ & $<0.0001$ & $<0.0001$ \\
Daily feed intake 60-74 days (g) & 152.4 & 146.6 & 3.34 & 0.2326 & 0.0366 & 0.5691 \\
Daily feed intake 32-74 days (g) & 116.0 & 123.8 & 3.47 & 0.2901 & 0.2607 & 0.3363 \\
\hline SE: standard error \\
The blocs consider rabbits from thefirst and second cycles
\end{tabular}


The average value of $119.9 \mathrm{~g}$ per day here measured is lower than the average value measured by Birolo et al. (2017) and Camargos et al. (2020). In addition to genetic and environmental parameters, this can also be explained by the low amount of fibers in the experimental feed $(13.5 \% \mathrm{ADF})$, a fact that contributes to a reduction in the passage rate. Gidenne et al. (2008b), Romero et al. (2010) and Oliveira et al. (2012) noticed lower values for daily consumption.

Results of feed conversion showed alternation in the superiority between the two groups, according to the period evaluated. In periods from 32 to 39 and 53 to 60 days (restricted periods), the rabbits with feed restriction had their growing limited by the amount of nutrients ingested, reverberating in a worse value of feed conversion, being this explained by the fact of the most part of nutrients are channeled for maintenance of the animal's tissues. However, in later periods, these animals proved to be more efficient for converting feed into body tissues, as also observed by Gidenne et al. (2008b).

Table 5 - Feed conversion in rabbits that received ad libitum or restricted feeding at different periods during fattening

\begin{tabular}{lcccccc}
\hline Parameter & Restricted & Ad libitum & SE & Pgroup & Pbloc & Pbloc*group \\
\hline Feed conversion 32-39 days & 2.49 & 2.11 & 0.23 & 0.2717 & 0.4684 & 0.1195 \\
Feed conversion 39-53 days & 2.55 & 2.89 & 0.11 & 0.0469 & 0.1224 & 0.3321 \\
Feed conversion 53-60 days & 5.19 & 4.05 & 0.51 & 0.1261 & 0.4069 & 0.9515 \\
Feed conversion 60-74 days & 3.87 & 4.75 & 0.16 & 0.0012 & 0.0069 & 0.3472 \\
Feed conversion 32-74 days & 3.22 & 3.36 & 0.09 & 0.2901 & 0.0024 & 0.5831 \\
\hline SE: standard error \\
The blocs consider rabbits from the first and second cycles
\end{tabular}

Romero et al. (2010) and Camargos et al. (2020) did not notice changes in feed conversion between rabbit with or without feed restriction. Even with a difference of 0.55 in the feed conversion value between the different feeding strategies, Oliveira et al. (2012) also did not notice any significant differences, which is probably inherent to the low number of repetitions used by the authors. However, when a large number of animals and repetitions are used (GIDENNE et al., 2008b; BIROLO et al., 2017) the positive influence of feed restriction on feed conversion becomes more evident and statistically significant.

The feed conversion value is the most important parameter for signalling profits on rabbit farms. Even though 
similar to Camargos et al. (2020), it is highlighted that the average value of 3.29 for feed conversion is worse than those found by Oliveira et al. (2012) (average value of 3.09), which reinforces the need to use a good quality rabbit diet that meets the nutritional needs of this specie. Comparing with Gidenne et al. (2008b), Romero et al. (2010) and Birolo et al. (2017), the differences are even greater (3.29 vs 2.54 vs 2.89 vs 2.93, respectively), which highlights too the need for improvements in the general conditions of Brazilian rabbit breeding, including here feed, ambience, management and genetics.

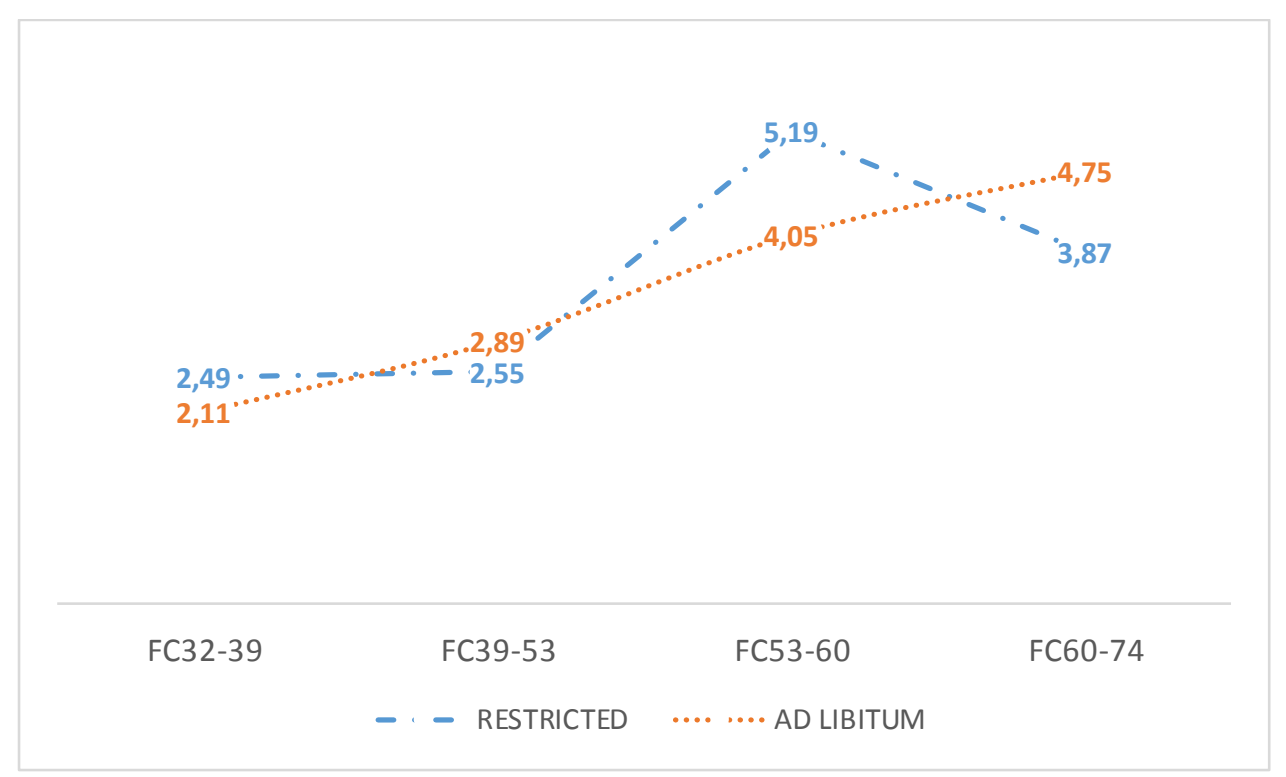

Graphic 2 - Feed conversion in rabbits that received ad libitum or restricted feeding.

FC32-39: Feed conversion from 32 to 39 days of age; FC39-53: Feed conversion from 39 to 53 days of age; FC53-60: Feed conversion from 53 to 60 days of age; FC60-74: Feed conversion from 60 to 74 days of age.

There were no significant that favor greater absorption of nutrients. differences in the digestibility These findings agree with Birolo et al. coefficients, thus suggesting that the feed (2017) and Gidenne et al. (2008a), restriction used in this study was not although the latter authors found sufficient to cause significant changes in improvements in crude protein the structure of the gastrointestinal tract digestibility from dietary restriction. 
Table 6 - Coefficients of apparent digestibility in rabbits that received ad libitum or restricted feeding during the fattening period.

\begin{tabular}{lcccc}
\hline Parameter & Restricted & Ad libitum & $\mathrm{P}$ & $\mathrm{vc}$ \\
\hline DCDM (\%) & 62.1 & 62.4 & 0.8830 & 5.23 \\
DCOM (\%) & 66.0 & 65.6 & 0.8026 & 4.19 \\
DCMM (\%) & 39.8 & 39.5 & 0.9284 & 18.81 \\
\hline
\end{tabular}

DCDM: digestibility coefficient of dry matter; DCOM: digestibility coefficient of organic matter; DCMM: digestibility coefficient of mineral matter.

\section{Conclusions}

During periods of feed restriction, there is a signific ant worsening in the parameters of productive performance in rabbits with feed restriction, with subsequent compensatory growth. Although there is no feed savings or improvement in the digestibility of dry matter, organic matter and mineral matter, feed restriction does not negatively influence the productive performance of rabbits during the fattening period, and can be an important strategy in farms with high post-weaning mortality rate, as suggested by several works. In this sense, experiments with high level of sanitary challenging could be performed.

New quantitative restriction programs, which assess the effects of percentage reduction in feed intake, may be important to better understand the process of feed restriction in fattening rabbits kept under Brazilian conditions.

\section{References}

BIROLO M., TROCINO A., TAZZOLI M., XICCATO G. Effect of feed restriction and feeding plans on performance, slaughter traits and body compositions of growing rabbits World Rabbit Science, v. 25, p. 113-122, 2017.

CAMARGOS R. S., MACHADO L. C., ZEFERINO C. P., BITTENCOURT $\mathrm{M}$. T., CAMPOS F. S. T., SANTOS A. M., SANTOS I. P., FARIA C. G. S. Feed restriction: productive performance, haematological parameters, gastrointestinal tract and carcass of rabbits. Revista Brasileira de Cunicultura, v. 17, p. 18-27, 2020.

GIDENNE T., FEUGIER A. Feed restriction strategy in the growing rabbit. 1. Impact on digestion, rate of passage and microbial activity. Animal, p. 1-8, 2008a.

GIDENNE T., COMBES S., FEUGIER A., JEHL N., ARVEUX P., BOISOT P., BRIENS C., CORRENT E., FORTUNE H., MONTESSUY S., VERDELHAN S. Feed restriction strategy in the growing rabbit. 2. Impact on digestive health, growth and carcass characteristics. Animal, p. 1-7, 2008b.

GIDENNE T. Feed intake regulation strategies for the growing rabbit: a 20052015 retrospective on economic and environmental impact in France. In: 
WOULD RABBIT CONGRESS, XII. Proceedings. Nantes, WRSA, 2021.

OLIVEIRA M. C., SILVA R. P., ARAÚJO L. S., SILVA V. R., BENTO E. A., SILVA D. M. Effect of feed restriction on performance of growing rabbits. Revista Brasileira de Zootecnia, v. 41, n. 6, p. 1463-1467, 2012.

OLIVEIRA M. C., SILVA D. M., DIAS D. M. B. Effect of feed restriction on organs and intestinal mucosa of growing rabbits. Revista Brasileira de Zootecnia, v. 42, n. 7, p. 530-534, 2013.

REBOURS G., RAFFIN J., VASTEL P., REYS S. Descriptive study of speed of , 2010. fattening rabbits' daily feed intake in constant and progressive hourly feeding with two nutritional levels of feed. In: WOULD RABBIT CONGRESS, XII. Proceedings. Nantes, WRSA, 2021.

RISI N. Panorama prático: Panorama do mercado de rações para coelhos. Boletim de Cunicultura, v. 22, p. 12-13, 2021.

ROMERO C., CUESTA S., ASTILLERO J. R., NICODEMUS N., De BLAS C. Effect of early feed restriction on performance and health status in growing rabbits slaughtered at 2 $\mathrm{kg}$ live-weight. World Rabbit Science, v. 18, p. 211-218, 2010. 